\title{
Combining Lidar and Synthetic Aperture Radar Data to Estimate Forest Biomass: Status and Prospects
}

\section{Sanna Kaasalainen 1,*, Markus Holopainen 2, Mika Karjalainen 1, Mikko Vastaranta ${ }^{2}$, Ville Kankare $^{2}$, Kirsi Karila ${ }^{1}$ and Batuhan Osmanoglu ${ }^{3}$}

1 Finnish Geospatial Research Institute, Geodeetinrinne 2, Masala FI-02431, Finland; E-Mails: mika.karjalainen@nls.fi (M.K.); kirsi.karila@fgi.fi (K.K.)

2 Department of Forest Sciences, University of Helsinki, P.O. Box 27, Helsinki FI-00014, Finland; E-Mails: markus.holopainen@helsinki.fi (M.H.); mikko.vastaranta@helsinki.fi (M.V.); ville.kankare@helsinki.fi (V.K.)

3 Biospheric Sciences Laboratory, University Space Research Association, NASA GSFC, Greenbelt, MD 20771, USA; E-Mail: batuhan.osmanoglu@nasa.gov

* Author to whom correspondence should be addressed; E-Mail: Sanna.Kaasalainen@nls.fi; Tel.: +358-50-3696806; Fax: +358-9-295-55211.

Academic Editors: Peter Beets and Eric J. Jokela

Received: 28 February 2014 / Accepted: 9 January 2015 / Published: 16 January 2015

\begin{abstract}
Research activities combining lidar and radar remote sensing have increased in recent years. The main focus in combining lidar-radar forest remote sensing has been on the retrieval of the aboveground biomass (AGB), which is a primary variable related to carbon cycle in land ecosystems, and has therefore been identified as an essential climate variable. In this review, we summarize the studies combining lidar and radar in estimating forest AGB. We discuss the complementary use of lidar and radar according to the relevance of the added value. The most promising prospects for combining lidar and radar data are in the use of lidar-derived ground elevations for improving large-area biomass estimates from radar, and in upscaling of lidar-based AGB data across large areas covered by spaceborne radar missions.
\end{abstract}

Keywords: lidar; radar; forest biomass; remote sensing; data fusion 


\section{Introduction}

\subsection{Background}

One of the key research topics in environmental and biospheric research is the cyclic flow of carbon on both local and global scales. As forests are one of the major carbon sinks in the global ecosystem, the aboveground biomass (AGB) is a primary variable related to the amount of carbon flowing in the cycle. Therefore, more accurate AGB estimations are needed to understand the carbon cycle in forest ecosystems [1-3]. Spatially explicit measurement of global biomass also supports the Reduction of Emissions due to Deforestation and Forest Degradation (REDD) mechanism and the international effort to reduce anthropogenic greenhouse gas emissions [4-7].

The main challenges in mapping AGB and its spatial distribution are the scarcity of field data and the limited resolution of remote measurements [8]. There is a gap between global and regional sampling of canopy height, which is a challenge for detailed AGB modelling. Extensive research is still needed for upscaling accurate local canopy height information across large-areas. The current allometric biomass equations are based on representative sampling, i.e., laborious field measurements, which are destructive and hard to obtain. Therefore it is difficult to acquire a representative sample, particularly for large areas. New and improved methods are called for, to fill this gap between regional and global information $(c f .[5])$.

\subsection{Lidar Remote Sensing}

Airborne Laser Scanning (ALS) comprises a light detection and ranging (lidar) instrument mounted on an airplane platform. ALS is an active remote sensing system based on monochromatic, pulsed lasers, Global Positioning System (GPS), and an Inertial Measurement Unit (IMU). Lidar instruments use the time-of-flight measurement principle to measure the distance to an object. With the known position of the sensor and the precise orientation of these range measurements between the sensor and a reflecting object, the three-dimensional position of an object is defined.

The instruments used for ALS-based forest AGB inventory purposes typically emit very short (3-10 ns), narrow beam width $(0.15-2.0 \mathrm{mrad})$, infrared $(0.80-1.55 \mu \mathrm{m})$ laser pulses at near-nadir incidence angles $\left(<30^{\circ}\right)$ with high pulse repetition frequencies $(50-200 \mathrm{kHz})$. When operated at flying altitudes of around 500-3000 m, ALS sensors generate a dense sample pattern $\left(0.5-20 \mathrm{pulses} / \mathrm{m}^{2}\right)$ with a small footprint $(<1 \mathrm{~m})$ on the ground.

When a laser pulse hits the forest canopy, it can produce one or more returns. In the simplest case, a laser pulse scatters directly from the top of the dense forest canopy or from the ground, resulting in a single return. Since the forest canopy is not a solid surface and there are gaps in the canopy cover, the situation becomes more complex when a laser pulse passes through the top of the canopy and interacts with different parts of the canopy, such as the trunk, branches, and leaves, before reaching the ground. This series of events may result in multiple returns being recorded for a single laser pulse. Some systems record the full waveform of the reflected laser pulse as well [9-11]. The first returns are mainly assumed to come from the top of the canopy and the last returns mainly from the ground, which is important for extracting the terrain surface. 
The trunks, branches, and leaves in dense vegetation tend to cause multiple scattering or absorption of the emitted laser energy so that fewer backscattered returns are reflected directly from the ground [12]. This effect increases when the canopy closure, canopy depth, and structure complexity increase because the laser pulse is greatly obscured by the canopy. In practice, the laser system specification and configurations also play an important role in how the laser pulse interacts with the forest.

ALS is currently a well-established operational method for the collection of high-resolution digital elevation models (DEM) [13-17]. ALS and the data interpretation algorithms have been developed and applied in environmental studies for more than two decades, while the number of applications has increased. Reviews on using ALS in forest inventory and AGB mapping have been provided in [7,18-21]. Spaceborne lidar have been used in the broad-scale inventory of boreal [22-24] and tropical [25] forest structures, and to provide vertical profiles of the canopy foliage [26]. An important spaceborne lidar is the Geoscience Laser Altimetry System (GLAS) on board NASA's ICESat (Ice, Cloud, and land Elevation Satellite), which provides individual footprints at a separation distance of $165 \mathrm{~m}$. GLAS has produced data for a large number of studies in recent years (e.g., [22,25-27]).

\subsection{Synthetic Aperture Radar}

Synthetic Aperture Radar (SAR) is an imaging radar operating at the microwave region of the electromagnetic spectrum. The main benefit of SAR is its ability to acquire data through clouds. Therefore it is a valuable instrument for earth observation from satellites. SAR imaging has been available in remote sensing since 1951 [28], and its applications cover a wide range in mapping and monitoring of natural resources. SAR data are available internationally from a large number of satellites with different frequency bands, polarizations, and variable imaging geometries [29]. Spaceborne SAR systems are pulse-based radars: a pulse of microwave radiation is transmitted and echoes returning from the target area are received. In principle, SAR signal data processed as a $2 \mathrm{D}$ image contains the following information per resolution cell: (1) intensity of the backscattered signal; (2) phase of the received radiation, which is relative to the range between the SAR antenna; and (3) the range from the antenna to the resolution cell. The main advantage of spaceborne SAR compared to optical imagery and ALS is the temporal frequency of imaging (see also [30-32]). Another current advantage of SAR over lidar is the global coverage provided by spaceborne instruments.

One of the main characteristics of a SAR system is the frequency band it operates on. The operating frequency of the radar is inversely proportional to the size of the microwave wavelength, and there are five common wavelengths available for scientific research. These are: $X-(\sim 3 \mathrm{~cm}), C-(\sim 6 \mathrm{~cm})$, S- $(\sim 15 \mathrm{~cm}), \mathrm{L}-(\sim 24 \mathrm{~cm})$, and P-band $(\sim 69 \mathrm{~cm})$ systems. A P-band $(\sim 69 \mathrm{~cm})$ SAR imaging system called Biomass is also planned by the European Space Agency, foreseen to be launched by 2020 . Excluding the effects of forest structure and other environmental conditions, different wavelengths have different penetration depths, such that the X-band echoes would predominantly come from tree leaves in a forest area, while the L- and P-band systems will reach further below, potentially reflecting back from the ground.

Forest 3D information can also be obtained using SAR. Phase information is used in InSAR data (interferometric synthetic aperture radar) to extract coherence maps and 3D information [33,34]. However, in forests, changes in the target area (e.g., those caused by wind) cause temporal decorrelation 
between the images and reduce the quality of the interferogram. In 2000, the Shuttle radar topography mission (SRTM) [35] provided simultaneous InSAR data that was mainly used for global elevation modelling. Currently, simultaneous InSAR data are available from the TanDEM-X system [36]. Polarimetric Interferometric SAR (PolInSAR) is an extension of SAR interferometry, which is sensitive to shape, orientation, and dielectric properties of the scattering target, and can be used to create detailed information of the forest structure [37]. In addition to TanDEM-X, airborne sensors such as DBSAR, UAVSAR, and E-SAR have generated imagery for PolInSAR analysis over forested areas [38]. In the past few years, radargrammetry has gained increasing interest, thanks to the high spatial resolution (down to $1 \mathrm{~m}$ ) and the high geolocation accuracy of modern SAR satellite systems $[39,40]$. Measurement accuracies below $10 \mathrm{~cm}$ have been obtained once the effect of known error sources has been removed. Radargrammetry is analogous to photogrammetric stereoscopic measurement: it is an alternative way to extract 3D data from SAR images besides InSAR processing [41].

\subsection{This Review}

An extensive review on the status and future of lidar, SAR, and other remote sensing methods for forest AGB can be found in [32]. Interferometric (InSAR) vegetation measurements are reviewed in [42].

Lidar-radar synergy is a topic of increasing interest and activity. Lidar-SAR integration approaches and using lidar data for improved interpretation of SAR data have been previously reviewed in [43]. In this review, we summarize the combined use of lidar and SAR in forest AGB detection and discuss different aspects on the combined use of lidar and radar. In the reviewed research, the AGB or AGB related parameters are predicted typically at the resolution varying from 100-1300 $\mathrm{m}^{2}$ (cf. [44]). The results are validated at the prediction resolution or at the stand level varying from $0.5-15$ ha. The validation resolution should be taken into account when comparing results between the studies (see Section 3).

The paper is organized as follows: we begin with an overview of lidar and radar in the remote sensing of forest AGB (Section 2). Joint lidar-radar studies in retrieving AGB and related forest parameters have been reviewed in Section 3, and the added value of the combined approach is discussed in Section 4, followed by a conclusion in Section 5 .

\section{Overview of Lidar and Radar in Forest Remote Sensing}

\subsection{Retrieval of AGB Using Area-Based Approach}

Remote sensing can be utilized for obtaining forest-related information at several levels. It can be carried out for purposes related to single trees, sample plots of varying size and shape, forest compartments or stands, and larger forested areas. Traditionally, remote sensing has been utilized in both stand-wise field inventories (SWFI) and sampling-based plot inventories to aid or enable map production. Most recently, lidar technology also enables measurements at the tree level.

Both lidar and radar signals are sensitive to the vertical structure of vegetation and other parameters that are crucial for monitoring forest ecosystems [45]. Lidar and radar instruments have been used extensively in the detection of AGB, canopy structure, and height (see Figures 1 and 2 for an example). The most used method to estimate AGB using lidar or SAR is the area-based approach (ABA), in which lidar or 
SAR data is used in deriving predictors that are then used as independent variables in models developed using co-located field plot measurements. The prediction resolution usually varies between $100-900 \mathrm{~m}^{2}$. Several techniques have been used to build predictive area-based AGB models, including parametric multiple linear regression and non-parametric nearest neighbor estimation techniques.

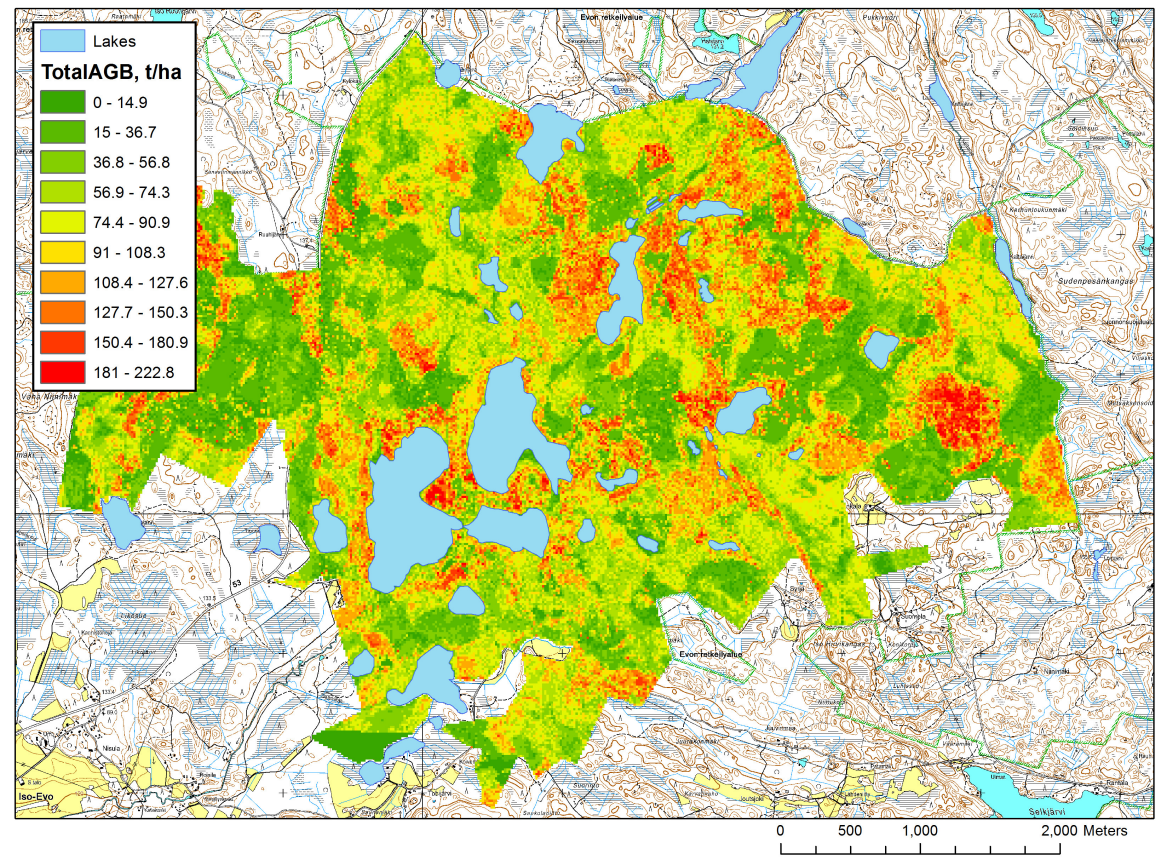

Figure 1. Aboveground biomass (AGB) estimation with lidar using area based approach in Evo, southern Finland.

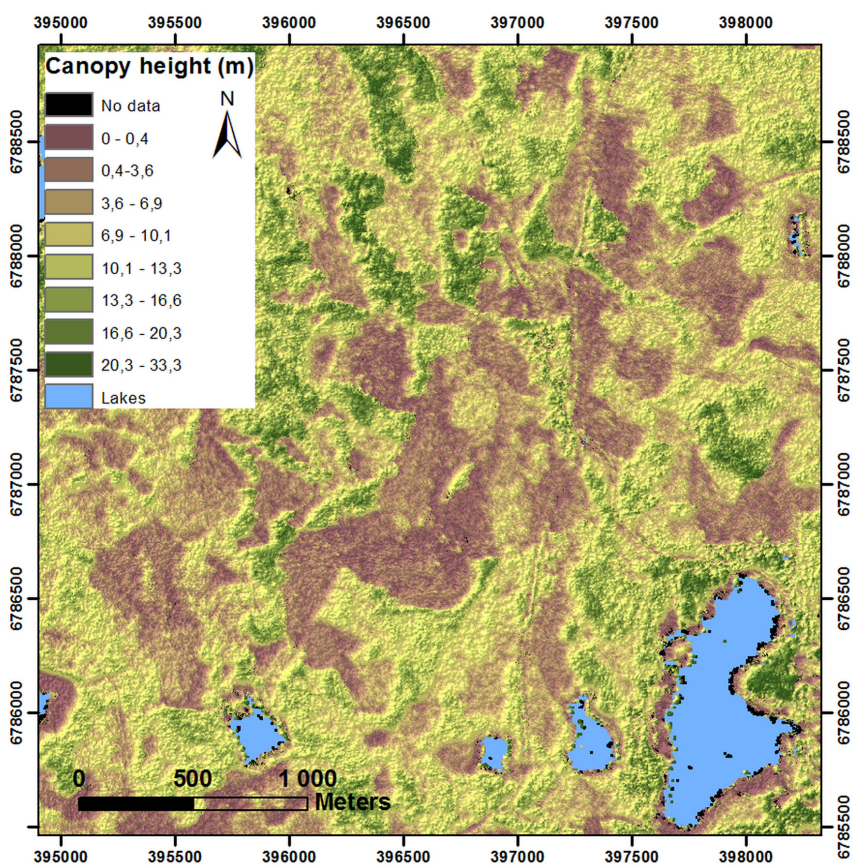

Figure 2. The airborne laser scanning (ALS)-based digital terrain model (DTM) of the Evo area ( $c f$. Figure 1) was subtracted from a digital surface model (DSM) derived from Tandem-X interferometric synthetic aperture radar (SAR) pair (29 June 2013) to get an InSAR canopy height model (CHM) (www.dlr.de). 


\subsection{Predictors (ALS, Profiling Lidar, Radar)}

Airborne laser scanning produces a georeferenced point cloud, from which it is possible to calculate Digital Terrain Models (DTM), Digital Surface Models (DSM) corresponding to tree tops (Figure 3), and 3D models of an object (e.g., Canopy Height Model CHM, normalized DSM), which are the main products of laser-assisted forest measurements [46]. The resolution of the above mentioned products is usually between $0.5 \mathrm{~m}$ and $2 \mathrm{~m}$. However, in ABA, the metrics derived from the normalized point cloud (i.e., point height are heights above the ground level) are mainly used as predictors, because they describe the whole structural variation in the canopy [46].

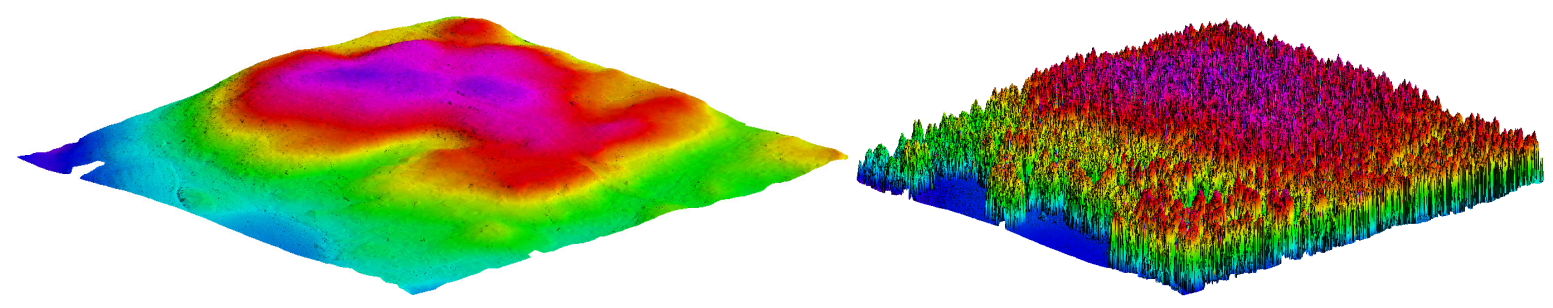

Figure 3. Examples of lidar DTM (left) and DSM (right).

Spaceborne lidars (such as ICESat GLAS) can provide accurate vegetation metrics (such as canopy height) from extensive areas [47,48]. However, the large footprint size (65 m for GLAS in [47]) of the spaceborne lidar affects the accuracy of results. Comparison of ICESat GLAS and ALS DTM accuracy is provided in [47], where an underestimation of about $2 \mathrm{~m}$ was found for GLAS. Especially, the accuracy of tree height estimates from GLAS decreased with increasing mean slope. Large errors were observed for spaceborne lidar by [24]: the errors began to approach $50 \%$ of ground reference AGB only above $70 \mathrm{Mg} / \mathrm{ha}$, i.e., characterizing differences in AGB was found to be difficult with current spaceborne sensors below $80 \mathrm{Mg} /$ ha with less than $50 \%-100 \%$ error.

SAR produces a complex valued image of the target. A pixel of a SAR image contains information on radar backscattering intensity, phase of the backscattered signal, and range measurement based on the time of flight information of the radar pulse. The relation of SAR intensity to forest AGB has been comprehensively discussed in [49]. There is a correlation between intensity and biomass, which strongly depends on the radar frequency. However, the main challenge is saturation, i.e., higher AGB volumes than the saturation level cannot be observed from the intensity data.

Interferometric coherence is obtained by calculating the cross-correlation coefficient between two complex SAR images using a moving window [33]. Relationship between the interferometric coherence and forest height was reported in [50]. It is necessary that the conditions do not change significantly between the image acquisitions, as in the case with simultaneous bistatic measurements provided by SRTM (Shuttle Radar Topography Mission) and TanDEM-X missions. Frozen winter conditions have been found suitable in boreal forests [51].

Height information is available from SAR imagery using radargrammetry or interferometry. In SAR interferometry, the phase difference of two complex SAR images (interferogram) is calculated. The phase differences can be converted to height differences to form a DSM [33,34]. For high quality DSMs, good coherence between the images is needed. Radargrammetry is based on stereoscopic measurement of SAR intensity images [52]. A suitable intersection angle between the images and similar 
conditions in both images are needed. In interferometry, the DSM height measured depends on the radar wavelength. If a DTM (or dual-wavelength SAR data) is available, heights above ground can be derived and used as predictors in AGB estimation.

\subsection{ABA (Area-Based Approach) Estimation of AGB Using ALS and SAR}

Area-based approach using ALS-derived predictors produces reliable estimates of AGB at the plot or stand level (e.g., [18,53-55]). ABA with lidar data have been used to estimate AGB at the detailed resolutions $\left(\sim 300 \mathrm{~m}^{2}\right)$. Canopy-based quantile estimators were applied in [56] to the estimation of AGB in an uneven-aged, hardwood forest. The results provided initial support for using lidar in AGB estimation with the coefficient of determinations being greater than 0.80. In [57], ALS was found capable of predicting biomass also in young forest stands $(0.5 \mathrm{ha})$ with an RMSE of $20 \%-30 \%$ of the mean ground value. AGB models using small-footprint discrete and full-waveform airborne lidar metrics performed well across the different subtropical forest types [58]. In boreal forest conditions, the RMSE-\% of ABA have varied from $17.5 \%$ to $32 \%$ with ALS data [55,59-61].

In most radar (SAR) applications, forest parameters are retrieved from the amplitude information in SAR backscatter (e.g., [62] and references therein), SAR interferometry, such as the SRTM [45], TanDEM-X [63], interferometric coherence [64], and polarimetric SAR interferometry (PolInSAR) in L- and P-band [37,65]. Using SAR intensity data, good results for forest AGB estimation have been obtained using a C-band sensor $(\sim 5.6 \mathrm{~cm})$ [30]. Due to saturation, forest AGB estimation using X-band $(\sim 3 \mathrm{~cm})$ radar intensity (stand level RMSE $56 \%$ ) has not been as accurate as that obtained with lidar data (RMSE 36\%) [31]. The saturation with L-band radar systems is around 100-250 Mg/ha, depending on the forest characteristics. The P-band radar systems should be able to measure biomass values well above $300 \mathrm{Mg} \cdot$ ha [66-68]. In [31], an RMSE accuracy of 56\% was achieved at a resolution of $200 \mathrm{~m}^{2}$ using TerraSAR-X intensity data. In [64], the relative RMSE of volume retrieval from single coherence images varied between $15 \%$ and $108 \%$ (stand level), while an RSME of $34 \%$ was achieved in multitemporal combination plot-level.

Forest parameter retrieval (including AGB) from SAR data has been previously reviewed in numerous papers: a summary of different approaches (based on backscatter, coherence, and phase) to using SAR in forest parameter estimation is provided in [62]. A review of forest biomass detection with InSAR is provided in [1,32], which provide an extensive review on the status and future of SAR for forest AGB, and InSAR vegetation measurements are reviewed in [42]. There is also a summary of lidar-SAR integration approaches in [43].

\section{Combining Lidar and Radar}

The combined lidar-radar activities in the detection of forest AGB are summarized in Table 1. In some studies, clear improvement resulted from combined use of lidar and SAR, whereas in others, little or no improvement from data fusion was observed. However, these studies also acknowledged the potential of using lidar as a sampling tool for regional-scale AGB estimation [42]. 
Table 1. Summary of studies of combined use of lidar and synthetic aperture radar (SAR) in biomass estimation. Abbreviations: above-ground biomass (AGB), digital terrain model (DTM), digital surface model (DSM), root mean square error (RMSE), airborne laser scanning (ALS).

\begin{tabular}{|c|c|c|c|c|c|}
\hline Activity & Application & SAR Description & Results & Accuracy & References \\
\hline \multirow{5}{*}{$\begin{array}{c}\text { Combined } \\
\text { lidar/SAR data: } \\
\text { joint use of SAR } \\
\text { and lidar in } \\
\text { biomass models. } \\
\text { SAR data combined } \\
\text { with lidar } \\
\text { DTM/DSM }\end{array}$} & AGB in tropical forests & L-band polarimetric SAR imagery & $100 \mathrm{~m}$ resolution AGB map & $\pm 25 \%$ uncertainty & {$[25]$} \\
\hline & $\begin{array}{l}\text { AGB \& canopy height in } \\
\text { temperate forests }\end{array}$ & $\begin{array}{l}\text { ALOS PALSAR polarimetry / } \\
\text { interferometry (C- \& L-band) }\end{array}$ & $\begin{array}{l}\text { Adding SAR variables improves the } \\
\text { lidar-based AGB estimation }\end{array}$ & RMSE is down to $7.1 \%-11.7 \%$ & [69] \\
\hline & AGB in temperate forests & $\begin{array}{l}\text { BioSAR cross-sections } \\
\quad(80-120 \mathrm{MHz})\end{array}$ & $\begin{array}{l}\text { Tree height from lidar data improves } \\
\text { the AGB estimation }\end{array}$ & $\begin{array}{c}R^{2}=0.80, \mathrm{RMSE}=21.3 \mathrm{t} / \mathrm{ha} \text { (profiling) and } \\
R^{2}=0.76, \mathrm{RMSE}=24.2 \mathrm{t} / \mathrm{ha} \text { (scanning) }\end{array}$ & [2] \\
\hline & $\begin{array}{l}\text { Forest height prediction } \\
\text { with statistical fusion }\end{array}$ & $\begin{array}{l}\text { C-band SRTM InSAR scattering } \\
\text { phase center }\end{array}$ & $\begin{array}{c}\text { Stand heights with tree } \\
\text { height from LVIS }\end{array}$ & $R^{2}=0.71, \mathrm{RMSE}=4.4 \mathrm{~m}(13 \%$ error $)$ & {$[45]$} \\
\hline & $\begin{array}{l}\text { Stereo radargrammetry } \& \\
\text { image pairs in boreal forests }\end{array}$ & $\begin{array}{l}\text { TanDEM-X DSM [70], Terra-SAR-X } \\
\text { image pairs in } 1 \mathrm{~m} \text { resolution [59] }\end{array}$ & $\begin{array}{l}\text { More accurate large-area } \\
\text { AGB using lidar DTM }\end{array}$ & $\begin{array}{c}\mathrm{RMSE}=57 \mathrm{~m}^{3} / \mathrm{ha}\left(\text { plot level) and } 25 \mathrm{~m}^{3} / \mathrm{ha}\right. \\
(\text { stand level) [70]. RMSE }=41.3 \mathrm{t} / \mathrm{ha}[59]\end{array}$ & {$[59,70]$} \\
\hline \multirow{3}{*}{$\begin{array}{c}\text { Data fusion: limited } \\
\text { or no improve-ment } \\
\text { from lidar/radar } \\
\text { data fusion. }\end{array}$} & $\begin{array}{l}\text { Forest inventory in the } \\
\text { boreal forest zone }\end{array}$ & $\begin{array}{l}\text { TerraSAR-X } \\
\text { images }\end{array}$ & $\begin{array}{l}\text { No improvement } \\
\text { compared to lidar alone }\end{array}$ & $\begin{array}{c}30 \% \text { error level resembling } \\
\text { manual inventories }\end{array}$ & {$[31]$} \\
\hline & $\begin{array}{l}\text { Stand level AGB + canopy } \\
\text { height (US pine forests) }\end{array}$ & $\mathrm{X}$ - and P- band SAR cross-sections & $\begin{array}{l}\text { Insignificant improvement } \\
\text { compared to lidar alone }\end{array}$ & $\begin{array}{c}\text { RMSE: } 33.9 \text { t/ha with lidar to } 32.7 \mathrm{t} / \mathrm{ha} \\
\text { combined [42], } 26.0 \mathrm{t} / \mathrm{ha} \text { to } 24.9 \mathrm{t} / \mathrm{ha} \\
\text { (with lidar canopy height) [71] }\end{array}$ & {$[42,71]$} \\
\hline & $\begin{array}{l}\text { Stand level AGB in Sierra } \\
\text { Nevada mixed forest }\end{array}$ & $\begin{array}{l}\text { X-band inter-ferometric phase } \\
\text { center \& } 10 \text { m reso-lution lidar DEM }\end{array}$ & $\begin{array}{l}\text { Lidar is the best sensor, addition of } \\
\mathrm{SAR} \rightarrow \text { marginal or no improvement }\end{array}$ & $\begin{array}{c}\text { RMSE }=75.3 \mathrm{Mg} / \text { ha with lidar alone and } \\
\text { with lidar }+ \text { InSAR, related to } \\
\text { field-measured biomass }\end{array}$ & {$[72]$} \\
\hline \multirow{6}{*}{$\begin{array}{l}\text { Upscaling: using } \\
\text { lidar and field } \\
\text { data as reference }\end{array}$} & $\begin{array}{c}\text { Norway spruce \& } \\
\text { pine AGB } \\
\end{array}$ & X-band InSAR & $\begin{array}{l}\text { ALS DEM improved } \\
\text { the AGB accuracy }\end{array}$ & $\mathrm{RMSE}=24 \mathrm{t} / \mathrm{ha}$ (spruce), 17t/ha (pine) & [1] \\
\hline & Northern hard-wood forests & L-band polarimetric SAR imagery & $\begin{array}{c}20 \mathrm{~m} \text { resolution ex-tended } \\
\text { to large areas }\end{array}$ & AGB with RMSE down to $203.9 \mathrm{Mg} / \mathrm{ha}$ & [6] \\
\hline & $\begin{array}{l}\text { AGB mapping in boreal } \\
\text { hard-wood forests }\end{array}$ & $\begin{array}{l}\text { L-band polarimetric SAR imagery \& } \\
\text { passive optical image combinations }\end{array}$ & $\begin{array}{l}\text { Accurate large-area AGB maps, lidar } \\
\text { combined with SAR \& optical images }\end{array}$ & $\begin{array}{l}\text { Reduced errors } 12 \%-38 \%(11-28 \mathrm{Mg} / \mathrm{ha}) \\
\text { from those where lidar is used with SAR } \\
\text { or optical alone }\end{array}$ & {$[73]$} \\
\hline & $\begin{array}{l}\text { AGB mapping in boreal } \\
\text { hard-wood forests }\end{array}$ & C-band polarimetric SAR imagery & $\begin{array}{l}\text { Accurate large-area AGB } \\
\text { maps with LVIS \& SAR }\end{array}$ & $\begin{array}{l}\text { AGB within } 10 \% \text { of the reference (lidar) } \\
\text { biomass map (RMSE } 31.33 \mathrm{Mg} / \mathrm{ha} \text { ) }\end{array}$ & {$[74]$} \\
\hline & AGB in tropical forests & $\mathrm{X}$ - and L-band SAR backscatter & Accurate large-area AGB maps & $R^{2}=0.53, \mathrm{RMSE}=79 \mathrm{t} / \mathrm{ha}$ & [4] \\
\hline & $\begin{array}{l}\text { Plot-level bio-mass in (sub) } \\
\text { tropical man-grove forests }\end{array}$ & $\begin{array}{c}\text { C-band SRTM interferometry } \\
\text { (90 m resolution) \& ICES at GLAS }\end{array}$ & $\begin{array}{c}\text { Extending lidar-based height/structure } \\
\text { data, estimation of biomass loss }\end{array}$ & $\begin{array}{l}\text { SRTM canopy height bias }(-1.3 \mathrm{~m}) \text { and } \\
\text { estimation error }(\mathrm{RMS}=1.9 \mathrm{~m})\end{array}$ & {$[75]$} \\
\hline
\end{tabular}




\subsection{AGB Estimation from Combined Lidar and SAR Data}

Accurate canopy height information from lidar data has been found to improve the AGB estimation in [2,69]. Models from fused data have been found useful for forest stand height characterization [45]. From the canopy height maps, AGB and carbon pools can be estimated using allometric equations $[22,45,54,55,62,76]$. Therefore, canopy height is an important parameter in AGB estimations if AGB is not directly predicted. The stem volume, also called the growing stock volume, is also an important AGB predictor (e.g., [30]). In boreal forest, $\sim 80 \%$ of the AGB is located in tree stems [55] and most often the stem volume can be converted to AGB using biomass expansion factors [77].

Many of the lidar-based AGB inventories have been focused on the northern forests dominated by spruce and pine [1,32,71]. Additional research for lidar-radar integration is important, especially in tropical and temperate forests, because of the vast amount of biomass in them: up to $40 \%$ of the terrestrial carbon is contained in tropical forests (see [4] and references therein). Lidar-radar data fusion has been applied to produce high-resolution AGB maps for large areas in tropical forests [25], where the information from dual-polarization SAR data was used along with a lidar DEM to classify the vegetation into biomass units with distinct biophysical parameters. This enabled the spatial extrapolation of the radar data. Not only the assessment of the current biomass status is needed: change detection methods are also called for, because of deforestation and forest damages [32,78].

Both lidar and radar are able to produce reasonable and consistent depictions of canopy height and AGB, but lidar has been found to have the highest precision and lower errors [32,79]. Little or no (statistically significant) improvement in AGB mapping was obtained by inclusion of SAR in $[42,71,72]$, particularly if the increased cost was considered (see also [80]). The results were similar for both scanning and profiling lidar [42,72]. One reason for this was suggested to be in the structure of an industrial plantation forest: the AGB is highly correlated with height, and the performance of lidar in height detection is superior to radar methods [42]. No added value was found in [31] for mixed tree species in plot level forest variable estimation, where the combined feature set was just marginally better than ALS alone. However, the potential of SAR images is in the better temporal resolution, so they could be combined with ALS for updating forest inventories. It has also been suggested that the future SAR systems may be more effective in producing the AGB for hardwood than for coniferous forests [42].

\subsection{Using Lidar DEM with Radar-Derived DSM}

One of the main aspects on combining lidar and radar in the estimation of forest inventory attributes is using lidar-derived DTM or DEM in conjunction with radar-derived DSM (e.g., [63,79]). Although this approach has resulted in improved AGB estimates, it is only applicable in the areas where a lidar-derived DTM is available. The combined use of lidar DTM with radar has proven useful in radargrammetry, which was recently applied for acquiring forest canopy height from stereo SAR imagery $[59,70,81]$. TerraSAR-X spotlight mode SAR stereo radargrammetry was able to derive favorable estimates for mean height and stem volume in Finland's boreal forest zone [59], where the boreal forest AGB and stem volume prediction accuracy was evaluated. Point-height metrics from ALS and TerraSAR-X stereo radargrammetry were used as predictors. MSEs of $29.9 \%$ and $30.2 \%$ were obtained for AGB and stem volume, respectively, when using radargrammetry-derived metrics. 
This was an improvement from previous studies and the accuracy was close to the estimation accuracy values from ALS only (21.9\% and 24.8\%). In [70], interferometric X-band SAR heights (from Tandem-X) were tested in the estimation of spruce stem volume and AGB. RMSE values of $43 \%-44 \%$ at the plot level and $19 \%-20 \%$ at the stand level were obtained using a nonlinear, mixed model.

In addition to combining DEM's with SAR data, ALS DEM's have also been found useful in improving the accuracy of results obtained with SAR (e.g., $[1,63,79])$.

\subsection{Upscaling}

One of the advantages of SAR is the wider spatial coverage compared to lidar: even though lidar data are more detailed, lidar does not usually cover as wide areas. Large-area AGB mapping with SAR using lidar sampling to improve the accuracy has been successfully carried out in $[1,4,6,73-75]$. The objective was to provide accurate large-area biomass information from SAR, while the accuracy could be improved with lidar and statistical methods. In most upscaling studies, lidar data is first calibrated with in situ reference data, after which the correlation between SAR signals and lidar-derived AGB is investigated [1,4,6,74]. Correlation between AGB and PALSAR signatures was studied in [74] using a reference biomass map of the region derived from LVIS lidar data. In this study, the stepwise regression was used for finding the best SAR variables and regression models for AGB estimation. The AGB was found to be within $10 \%$ of the reference biomass map (from LVIS lidar data) with an RMSE of $31.33 \mathrm{Mg} / \mathrm{ha}$. Considering the superior performance of lidar in numerous studies $[31,32,59,72]$, the study shows the upscaling prospect with lidar sampling and spatial modelling methods to be a promising one. The wall-to-wall extension of $20 \mathrm{~m}$ resolution also demonstrated the high potential of lidar sampling for large-area AGB mapping [6].

Accurate data from large areas are needed for important climate-change related issues, such as understanding the global carbon budget, assessing biodiversity, or monitoring protected areas $[73,82]$. These issues are pronounced in tropical forests, for which upscaling produces information on AGB and canopy height and their spatial variation $[4,75,80]$. Synergy between future spaceborne lidar and radar missions would help improve the coverage and sampling of current methods (e.g., [73]). The potential for extending lidar-based canopy height profiles with SAR was pointed out in a study combining GLAS with SRTM [75,83].

\section{Discussion}

\subsection{The Main Assets and Drawbacks of Lidar and SAR Methods}

Both lidar and radar have their advantages and drawbacks, which have been pointed out in many studies reviewed in Section 3. The combined lidar-SAR activities aim at compensating the drawbacks in AGB detection with additional input from the other method.

Lidar is capable of providing accurate structure information, such as the vertical structure and leaf distribution in the canopy. The reliability of lidar in producing canopy height and density has been noted in many studies $[6,43,45,79]$ and this leads to accurate biomass estimation. The accuracy of lidar 
measurements is often higher and there are fewer systematic errors with respect to field measurement than in the experiments based on radar interferometry (e.g., [79]).

The downside of ALS is the high cost of airborne data acquisition [1,2,84], especially as AGB mapping in regional scales is needed to improve global models $[6,45]$. This reported the total cost of full lidar acquisition at an area of $25 \mathrm{~km}^{2}$ to be $\$ 25,000 \mathrm{CAD}$ in 2013. Also, the lack of temporal consistency limits the availability of continuous monitoring [70]. Uncertainty in deriving the AGB from lidar waveforms was discussed in [74], in which error sources, such as mismatch between locations of field and lidar measurements, are identified.

The strengths of radar for global and continuous coverage complement those of lidar [73,74]. The main problems are saturation, limited accuracy, and spatial resolution, which prevent the detailed measurement in individual tree or stand level $[1,6,70]$ or cause errors in derived canopy heights used in the AGB predictions [63]. The capability of data acquisition through clouds is also a potential advantage of radar sensors [42].

\subsection{Added Value from Combining Lidar and Radar}

The most recent studies of combined lidar and SAR observations indicate the potential of improving and upscaling SAR data with lidar. According to the summary presented in Section 3, we find the most promising aspects of combining lidar and SAR to be:

(1) Using lidar DEM/DSM: lidar-based ground elevation for canopy height retrieval from SAR imagery (as in radargrammetry), or improving SAR-based AGB maps using canopy heights from lidar DSM (see Table 1 for examples).

(2) Upscaling: extending accurate height/structure data from lidar with statistical methods to provide large-area biomass information using SAR.

Lidar-derived accurate measurements of ground surface elevation, canopy height, and vertical structure can help improve the wall-to-wall SAR measurements of AGB. A high-quality DTM from ALS was used along with interferometric X-band SAR in [1], resulting in an AGB estimation with a higher accuracy as compared to using alternative DTM's from topographic maps. Lidar-derived elevation data is also required to normalize heights from interferometry or radargrammetry to heights above the ground: a DTM from ALS can be used as a reference to derive a Canopy Height Model (CHM) or an InSAR height model. In [70], a $10 \mathrm{~m} \times 10 \mathrm{~m}$ CHM was derived from TanDEM-X image pairs. The volume and AGB were then determined statistically from InSAR height data. The 3D SAR data with DTM as input were shown to be a promising tool for accurate AGB monitoring.

Spatially explicit biomass and vegetation height estimates would be possible to obtain for large areas by upscaling lidar transects across continuous areas. This requires improving the accuracy of large-area SAR data with lidar (which is first calibrated with field data) and statistical methods $[1,6,23,45]$. The first results have shown a good correlation between lidar-SAR AGB maps and lidar-field data [74]. The main challenges in upscaling are related to finding a relationship between SAR backscatter coefficient and lidar-derived AGB [4]. In some cases this may be due to the complexity of plots [85], but the field sampling has to be extensive enough to cover a range of forest structures [74]. The field sampling is used in many applications to calibrate the lidar-derived AGB (e.g., [1,6]). For the wall-to-wall extension of 
AGB maps with SAR, the lidar sampling has to be statistically and geometrically representative to characterize the structure and variation of the stands [6]. It is also important that both data are collected at the same time to avoid the effect of changes, such as growth and mortality $[1,74]$.

There were studies that found little or no added value from lidar-SAR data fusion (Table 1). Many of these studies were carried out at stand level, whereas added value from combined lidar and SAR was mostly found in large-area applications, where the broad coverage of SAR was an asset. Whether this is a question of scale, needs further study, but it seems that little added value from SAR was achieved in such cases where lidar was enough to cover the entire study area, such as in [42], where airborne SAR and lidar data from the same area were combined. However, the potential of combining the accuracy of lidar and the broader coverage of SAR in large-area AGB estimations was acknowledged even when no improvement was evident at the stand level $[42,71]$.

\section{Summary and Future Prospects}

\subsection{Conclusions}

Accurate biomass information is crucial for the study of carbon in the global ecosystem, sustainable forest management (cf. [21]), and mapping forest damages and degradation [82,86,87]. This will be achieved with combined lidar-radar remote sensing, which has gained more international interest quite recently.

In this paper we have provided a summary of combined lidar-SAR methods for forest AGB detection. From the studies carried out thus far, it seems that the main advantage of combining lidar and SAR may be in large-area applications, particularly, improving SAR-based AGB estimation with lidar DEMs or upscaling accurate lidar metrics to large areas with SAR data. Thus the state-of-the-art development in joint lidar-radar studies shows the potential for continuous global biomass mapping with improved accuracy. Global, spatially detailed, and accurate DTM enables for different aspects on regional scale remote sensing, such as radargrammetry, photogrammetry, etc. More research on combined SAR data and lidar sampling is needed for upscaling accurate biomass data into global level. This requires extensive field and lidar studies to improve statistics, and establish a link between lidar sampling and SAR data, thus filling the gap between regional and global scale biomass information. This is particularly important in the areas where less data are available, such as tropical forests.

\subsection{Future Prospects}

The main focus of this paper is on the applications and results from joint lidar-radar studies. There is still a need for a further study of technology readiness level to survey the needs of end-users. While there are still quite a few challenges, there are some important new technologies and aspects, which will reshape the future efforts for regional biomass detection:

- Spaceborne lidar will be able to provide large-area validation for SAR. More space lidar missions can be expected in the near future, such as the ICESAT-2 [26] and NASA's GEDI to be launched in 2018 (see http://science.nasa.gov/missions/gedi/).

- One of the major data sources in the future is satellite remote sensing (cf. [70]), and the spatial resolution of the future is improving. The upcoming ESA BIOMASS (SAR) mission will 
provide biomass data at a spatial scale of 100-200 m from intensity data, combined with forest height from polarimetry [5]. The results from TanDEM-X bistatic InSAR are good [63]. Therefore, a new bistatic InSAR mission (e.g., for ESA Sentinel-1A and 1B) would be relevant for biomass estimation.

- Structural modelling from terrestrial laser scanning is a growing field of study, and it will provide a robust alternative for laborious field sampling, especially as the improved instrumentation and modeling also account for the branch structure [88-90]. TLS methods could then replace manual field inventories in validating the lidar-based ground reference in improving the accuracy of the large-area AGB with SAR (e.g., in [1]).

\section{Acknowledgments}

This study has been financially supported by the following: Academy of Finland projects: "New techniques in active remote sensing: hyperspectral laser in environmental change detection", "Mobilaser", "Science and Technology Towards Precision Forestry", and "Centre of Excellence in Laser Scanning Research (CoE-LaSR)". This work was also supported by the ESA Dragon3 Young Research Scientist Project (ESRIN/Contract No. 4000109483/13/I-BG) and the research leading to these results has received funding from the European Community's Seventh Framework Programme (FP7/2007-2013) under grant agreement No. 606971. The TanDEM-X data was obtained through TanDEM-X pre-operational AO (project No. XTI-VEGE0360). Authors also thank reviewers 1 and 3 for their objective comments.

\section{Author Contributions}

Sanna Kaasalainen, Markus Holopainen, and Mikko Vastaranta were the main authors of the introduction and background parts. Mika Karjalainen and Batuhan Osmanoglu contributed to the writing and references, especially to parts related to SAR and radargrammetry. Ville Kankare and Kirsi Karila provided text, figures, and references.

\section{Conflicts of Interest}

The authors declare no conflict of interest.

\section{References}

1. Solberg, S.; Astrup, R.; Gobakken, T.; Næsset, E.; Weydahl, D.J. Estimating spruce and pine biomass with interferometric X-band SAR. Remote Sens. Environ. 2010, 114, 2353-2360.

2. Banskota, A.; Wynne, R.H.; Johnson, P.; Emessiene, B. Synergistic use of very high-frequency radar and discrete-return lidar for estimating biomass in temperate hardwood and mixed forests. Ann. For. Sci. 2011, 68, 347-356.

3. Neigh, C.; Tucker, C.; Townshend, J. North American vegetation dynamics observed with multi-resolution satellite data. Remote Sens. Environ. 2008, 112, 1749-1772.

4. Englhart, S.; Keuck, V.; Siegert, F. Aboveground biomass retrieval in tropical forests-The potential of combined X- and L-band SAR data use. Remote Sens. Environ. 2011, 115, 1260-1271. 
5. Le Toan, T.; Quegan, S.; Davidson, M.W.J.; Balzter, H.; Paillou, P.; Papathanassiou, K.; Plummer, S.; Rocca, F.; Saatchi, S.; Shugart, H.; et al. The BIOMASS mission: Mapping global forest biomass to better understand the terrestrial carbon cycle. Remote Sens. Environ. 2011, 115, 2850-2860.

6. Tsui, O.W.; Coops, N.C.; Wulder, M.A.; Marshall, P.L. Integrating airborne LiDAR and space-borne radar via multivariate kriging to estimate above-ground biomass. Remote Sens. Environ. 2013, 139, 340-352.

7. Skowronski, N.S.; Clark, K.L.; Gallagher, M.; Birdsey, R.A.; Hom, J.L. Airborne laser scanner-assisted estimation of aboveground biomass change in a temperate oak-pine forest. Remote Sens. Environ. 2014, 151, 166-174.

8. Hancock, S.; Lewis, P.; Foster, M.; Disney, M.; Muller, J.-P. Measuring forests with dual wavelength lidar: A simulation study over topography. Agric. For. Meteorol. 2012, 161, 123-133.

9. Wagner, W.; Ullrich, A.; Ducic, V.; Melzer, T.; Studnicka, N. Gaussian decomposition and calibration of a novel small-footprint full-waveform digitising airborne laser scanner. ISPRS J. Photogramm. Remote Sens. 2006, 60, 100-112.

10. Reitberger, J.; Schnörr, C.; Krzystek, P.; Stilla, U. 3D segmentation of single trees exploiting full waveform LIDAR data. ISPRS J. Photogramm. Remote Sens. 2009, 64, 561-574.

11. Mallet, C.; Bretar, F.; Roux, M.; Soergel, U.; Heipke, C. Relevance assessment of full-waveform lidar data for urban area classification. ISPRS J. Photogramm. Remote Sens. 2011, 66, S71-S84.

12. Harding, D.; Lefsky, M.; Parker, G.; Blair, J. Laser altimeter canopy height profiles: Methods and validation for closed-canopy, broadleaf forests. Remote Sens. Environ. 2001, 76, 283-297.

13. Kraus, K.; Pfeifer, N. Determination of terrain models in wooded areas with airborne laser scanner data. ISPRS J. Photogramm. Remote Sens. 1998, 53, 193-203.

14. Ackermann, F. Airborne laser scanning-present status and future expectations. ISPRS J. Photogramm. Remote Sens. 1999, 54, 64-67.

15. Wehr, A.; Lohr, U. Airborne laser scanning-An introduction and overview. ISPRS J. Photogramm. Remote Sens. 1999, 54, 68-82.

16. Vosselman, G.; Kessels, P.; Gorte, B. The utilisation of airborne laser scanning for mapping. Int. J. Appl. Earth Obs. Geoinf. 2005, 6, 177-186.

17. Mallet, C.; Bretar, F. Full-waveform topographic lidar: State-of-the-art. ISPRS J. Photogramm. Remote Sens. 2009, 64, 1-16.

18. Næsset, E. Accuracy of forest inventory using airborne laser scanning: Evaluating the first Nordic full-scale operational project. Scand. J. For. Res. 2004, 19, 554-557.

19. Koch, B.; Straub, C.; Dees, M.; Wang, Y.; Weinacker, H. Airborne laser data for stand delineation and information extraction. Int. J. Remote Sens. 2009, 30, 935-963.

20. Hyyppä, J.; Yu, X.; Hyyppä, H.; Vastaranta, M.; Holopainen, M.; Kukko, A.; Kaartinen, H.; Jaakkola, A.; Vaaja, M.; Koskinen, J.; et al. Advances in Forest Inventory Using Airborne Laser Scanning. Remote Sens. 2012, 4, 1190-1207.

21. Wulder, M.A.; White, J.C.; Nelson, R.F.; Næsset, E.; Ørka, H.O.; Coops, N.C.; Hilker, T.; Bater, C.W.; Gobakken, T. Lidar sampling for large-area forest characterization: A review. Remote Sens. Environ. 2012, 121, 196-209. 
22. Neigh, C.S.R.; Nelson, R.F.; Ranson, K.J.; Margolis, H.A.; Montesano, P.M.; Sun, G.; Kharuk, V.; Næsset, E.; Wulder, M.A.; Andersen, H.-E. Taking stock of circumboreal forest carbon with ground measurements, airborne and spaceborne LiDAR. Remote Sens. Environ. 2013, 137, 274-287.

23. Bergen, K.M.; Goetz, S.J.; Dubayah, R.O.; Henebry, G.M.; Hunsaker, C.T.; Imhoff, M.L.; Nelson, R.F.; Parker, G.G.; et al. Remote sensing of vegetation 3-D structure for biodiversity and habitat: Review and implications for lidar and radar spaceborne missions. J. Geophys. Res. 2009, 114, doi:10.1029/2008JG000883.

24. Montesano, P.M.; Nelson, R.F.; Dubayah, R.O.; Sun, G.; Cook, B.D.; Ranson, K.J.R.; Næsset, E.; Kharuk, V. The uncertainty of biomass estimates from LiDAR and SAR across a boreal forest structure gradient. Remote Sens. Environ. 2014, 154, 398-407.

25. Mitchard, E.T.A.; Saatchi, S.S.; White, L.J.T.; Abernethy, K.A.; Jeffery, K.J.; Lewis, S.L.; Collins, M.; Lefsky, M.A.; Leal, M.E.; Woodhouse, I.H.; et al. Mapping tropical forest biomass with radar and spaceborne LiDAR in Lopé National Park, Gabon: Overcoming problems of high biomass and persistent cloud. Biogeosciences 2012, 9, 179-191.

26. Tang, H.; Brolly, M.; Zhao, F.; Strahler, A.H.; Schaaf, C.L.; Ganguly, S.; Zhang, G.; Dubayah, R. Deriving and validating Leaf Area Index (LAI) at multiple spatial scales through lidar remote sensing: A case study in Sierra National Forest, CA. Remote Sens. Environ. 2014, 143, 131-141.

27. Carabajal, C.C.; Harding, D.J. ICESat validation of SRTM C-band digital elevation models. Geophys. Res. Lett. 2005, 32.

28. Franceschetti, G.; Lanari, R. Synthetic Aperture Radar Processing; CRC Press: London, UK, 1999.

29. Ouchi, K. Recent Trend and Advance of Synthetic Aperture Radar with Selected Topics. Remote Sens. 2013, 5, 716-807.

30. Santoro, M.; Beer, C.; Cartus, O.; Schmullius, C.; Shvidenko, A.; McCallum, I.; Wegmüller, U.; Wiesmann, A. Retrieval of growing stock volume in boreal forest using hyper-temporal series of Envisat ASAR ScanSAR backscatter measurements. Remote Sens. Environ. 2011, 115, 490-507.

31. Holopainen, M.; Haapanen, R.; Karjalainen, M.; Vastaranta, M.; Hyyppä, J.; Yu, X.; Tuominen, S.; Hyyppä, H. Comparing Accuracy of Airborne Laser Scanning and TerraSAR-X Radar Images in the Estimation of Plot-Level Forest Variables. Remote Sens. 2010, 2, 432-445.

32. Koch, B. Status and future of laser scanning, synthetic aperture radar and hyperspectral remote sensing data for forest biomass assessment. ISPRS J. Photogramm. Remote Sens. 2010, 65, 581-590.

33. Bamler, R.; Hartl, P. Synthetic aperture radar interferometry. Inverse Probl. 1998, 14, R1-R54.

34. Massonnet, D.; Feigl, K.L. Radar interferometry and its application to changes in the Earth's surface. Rev. Geophys. 1998, 36, 441.

35. Werner, M. Shuttle Radar Topography Mission (SRTM) Mission Overview. Frequenz 2001, 55, $75-79$.

36. Krieger, G.; Moreira, A.; Fiedler, H.; Hajnsek, I.; Werner, M.; Younis, M.; Zink, M. TanDEM-X: A Satellite Formation for High-Resolution SAR Interferometry. IEEE Trans. Geosci. Remote Sens. 2007, 45, 3317-3341. 
37. Papathanassiou, K.P.; Cloude, S.R. Single-baseline polarimetric SAR interferometry. IEEE Trans. Geosci. Remote Sens. 2001, 39, 2352-2363.

38. Robinson, C.; Saatchi, S.; Neumann, M.; Gillespie, T. Impacts of Spatial Variability on Aboveground Biomass Estimation from L-Band Radar in a Temperate Forest. Remote Sens. 2013, 5, 1001-1023.

39. Raggam, H.; Gutjahr, K.; Perko, R.; Schardt, M. Assessment of the Stereo-Radargrammetric Mapping Potential of TerraSAR-X Multibeam Spotlight Data. IEEE Trans. Geosci. Remote Sens. 2010, 48, 971-977.

40. Eineder, M.; Minet, C.; Steigenberger, P.; Cong, X.; Fritz, T. Imaging Geodesy-Toward Centimeter-Level Ranging Accuracy with TerraSAR-X. IEEE Trans. Geosci. Remote Sens. 2011, 49, 661-671.

41. Nurminen, K.; Karjalainen, M.; Yu, X.; Hyyppä, J.; Honkavaara, E. Performance of dense digital surface models based on image matching in the estimation of plot-level forest variables. ISPRS J. Photogramm. Remote Sens. 2013, 83, 104-115.

42. Nelson, R.F.; Hyde, P.; Johnson, P.; Emessiene, B.; Imhoff, M.L.; Campbell, R.; Edwards, W. Investigating RaDAR - LiDAR synergy in a North Carolina pine forest. Remote Sens. Environ. 2007, 110, 98-108.

43. Lucas, R.; Lee, A.; Armston, J.; Breyer, J.; Bunting, P.; Carreiras, J. Advances in Forest Characterisation, Mapping and Monitoring through Integration of LiDAR and Other Remote Sensing Datasets. In Proceedings of the SilviLaser 2008: the 8th International Conference on LiDAR Applications in Forest Assessment and Inventory, Edinburgh, UK, 17-19 September 2008.

44. Vastaranta, M.; Niemi, M.; Karjalainen, M.; Peuhkurinen, J.; Kankare, V.; Hyyppä, J.; Holopainen, M. Prediction of Forest Stand Attributes Using TerraSAR-X Stereo Imagery. Remote Sens. 2014, 6, 3227-3246.

45. Kellndorfer, J.M.; Walker, W.S.; LaPoint, E.; Kirsch, K.; Bishop, J.; Fiske, G. Statistical fusion of lidar, InSAR, and optical remote sensing data for forest stand height characterization: A regional-scale method based on LVIS, SRTM, Landsat ETM+, and ancillary data sets. J. Geophys. Res. 2010, 115, doi:10.1029/2009JG000997.

46. White, J.; Wulder, M.; Vastaranta, M.; Coops, N.; Pitt, D.; Woods, M. The Utility of Image-Based Point Clouds for Forest Inventory: A Comparison with Airborne Laser Scanning. Forests 2013, 4 , 518-536.

47. Hilbert, C.; Schmullius, C. Influence of Surface Topography on ICESat/GLAS Forest Height Estimation and Waveform Shape. Remote Sens. 2012, 4, 2210-2235.

48. Bolton, D.K.; Coops, N.C.; Wulder, M.A. Investigating the agreement between global canopy height maps and airborne Lidar derived height estimates over Canada. Can. J. Remote Sens. 2013, 39, S139-S151.

49. Le Toan, T.; Beaudoin, A.; Riom, J.; Guyon, D. Relating forest biomass to SAR data. IEEE Trans. Geosci. Remote Sens. 1992, 30, 403-411.

50. Hagberg, J.O.; Ulander, L.M.H.; Askne, J. Repeat-pass SAR interferometry over forested terrain. IEEE Trans. Geosci. Remote Sens. 1995, 33, 331-340.

51. Santoro, M.; Askne, J.; Smith, G.; Fransson, J.E. Stem volume retrieval in boreal forests from ERS-1/2 interferometry. Remote Sens. Environ. 2002, 81, 19-35. 
52. Leberl, F. Accuracy analysis of stereo side-looking radar. Photogramm. Eng. Remote Sens. 1979, 45, 1083-1096.

53. Lim, K.; Treitz, P.; Wulder, M.; St-Onge, B.; Flood, M. LiDAR remote sensing of forest structure. Progr. Phys. Geogr. 2003, 27, 88-106.

54. Vastaranta, M.; Kankare, V.; Holopainen, M.; Yu, X.; Hyyppä, J.; Hyyppä, H. Combination of individual tree detection and area-based approach in imputation of forest variables using airborne laser data. ISPRS J. Photogramm. Remote Sens. 2012, 67, 73-79.

55. Kankare, V.; Vastaranta, M.; Holopainen, M.; Räty, M.; Yu, X.; Hyyppä, J.; Hyyppä, H.; Alho, P.; Viitala, R. Retrieval of Forest Aboveground Biomass and Stem Volume with Airborne Scanning LiDAR. Remote Sens. 2013, 5, 2257-2274.

56. Lim, K.S.; Treitz, P.M. Estimation of above ground forest biomass from airborne discrete return laser scanner data using canopy-based quantile estimators. Scand. J. For. Res. 2004, 19, 558-570.

57. Næsset, E. Estimating above-ground biomass in young forests with airborne laser scanning. Int. J. Remote Sens. 2011, 32, 473-501.

58. Cao, L.; Coops, N.; Hermosilla, T.; Innes, J.; Dai, J.; She, G. Using Small-Footprint Discrete and Full-Waveform Airborne LiDAR Metrics to Estimate Total Biomass and Biomass Components in Subtropical Forests. Remote Sens. 2014, 6, 7110-7135.

59. Vastaranta, M.; Holopainen, M.; Karjalainen, M.; Kankare, V.; Hyyppa, J.; Kaasalainen, S. TerraSAR-X Stereo Radargrammetry and Airborne Scanning LiDAR Height Metrics in Imputation of Forest Aboveground Biomass and Stem Volume. IEEE Trans. Geosci. Remote Sens. 2014, 52 , 1197-1204.

60. Nyström, M.; Holmgren, J.; Olsson, H. Prediction of tree biomass in the forest-tundra ecotone using airborne laser scanning. Remote Sens. Environ. 2012, 123, 271-279.

61. Næsset, E.; Gobakken, T. Estimation of above- and below-ground biomass across regions of the boreal forest zone using airborne laser. Remote Sens. Environ. 2008, 112, 3079-3090.

62. Balzter, H.; Rowland, C.; Saich, P. Forest canopy height and carbon estimation at Monks Wood National Nature Reserve, UK, using dual-wavelength SAR interferometry. Remote Sens. Environ. 2007, 108, 224-239.

63. Askne, J.; Fransson, J.; Santoro, M.; Soja, M.; Ulander, L. Model-Based Biomass Estimation of a Hemi-Boreal Forest from Multitemporal TanDEM-X Acquisitions. Remote Sens. 2013, 5, 5574-5597.

64. Askne, J.; Santoro, M.; Smith, G.; Fransson, J.E.S. Multitemporal repeat-pass SAR interferometry of boreal forests. IEEE Trans. Geosci. Remote Sens. 2003, 41, 1540-1550.

65. Neumann, M.; Saatchi, S.S. Assessing Performance of L- and P-Band Polarimetric Interferometric SAR Data in Estimating Boreal Forest Above-Ground Biomass. IEEE Trans. Geosci. Remote Sens. 2014, 50, 714-726.

66. Lucas, R.; Armston, J.; Fairfax, R.; Fensham, R.; Accad, A.; Carreiras, J.; Kelley, J.; Bunting, P.; Clewley, D.; Bray, S.; et al. An Evaluation of the ALOS PALSAR L-Band Backscatter; Above Ground Biomass Relationship Queensland, Australia: Impacts of Surface Moisture Condition and Vegetation Structure. IEEE J. Sel. Top. Appl. Earth Obs. Remote Sens. 2010, 3, 576-593. 
67. Ho Tong Minh, D.; Toan, T.L.; Rocca, F.; Tebaldini, S.; d’Alessandro, M.M.; Villard, L. Relating P-Band Synthetic Aperture Radar Tomography to Tropical Forest Biomass. IEEE Trans. Geosci. Remote Sens. 2014, 52, 967-979.

68. Rauste, Y. Multi-temporal JERS SAR data in boreal forest biomass mapping. Remote Sens. Environ. 2005, 97, 263-275.

69. Tsui, O.W.; Coops, N.C.; Wulder, M.A.; Marshall, P.L.; McCardle, A. Using multi-frequency radar and discrete-return LiDAR measurements to estimate above-ground biomass and biomass components in a coastal temperate forest. ISPRS J. Photogramm. Remote Sens. 2012, 69, 121-133.

70. Solberg, S.; Astrup, R.; Breidenbach, J.; Nilsen, B.; Weydahl, D. Monitoring spruce volume and biomass with InSAR data from TanDEM-X. Remote Sens. Environ. 2013, 139, 60-67.

71. Hyde, P.; Nelson, R.; Kimes, D.; Levine, E. Exploring LiDAR-RaDAR synergy_Predicting aboveground biomass in a southwestern ponderosa pine forest using LiDAR, SAR and InSAR. Remote Sens. Environ. 2007, 106, 28-38.

72. Hyde, P.; Dubayah, R.; Walker, W.; Blair, J.B.; Hofton, M.; Hunsaker, C. Mapping forest structure for wildlife habitat analysis using multi-sensor (LiDAR, SAR/InSAR, ETM+, Quickbird) synergy. Remote Sens. Environ. 2006, 102, 63-73.

73. Montesano, P.M.; Cook, B.D.; Sun, G.; Simard, M.; Nelson, R.F.; Ranson, K.J.; Zhang, Z.; Luthcke, S. Achieving accuracy requirements for forest biomass mapping: A spaceborne data fusion method for estimating forest biomass and LiDAR sampling error. Remote Sens. Environ. 2013, 130, 153-170.

74. Sun, G.; Ranson, K.J.; Guo, Z.; Zhang, Z.; Montesano, P.; Kimes, D. Forest biomass mapping from lidar and radar synergies. Remote Sens. Environ. 2011, 115, 2906-2916.

75. Simard, M.; Rivera-Monroy, V.H.; Mancera-Pineda, J.E.; Castañeda-Moya, E.; Twilley, R.R. A systematic method for 3D mapping of mangrove forests based on Shuttle Radar Topography Mission elevation data, ICEsat/GLAS waveforms and field data: Application to Ciénaga Grande de Santa Marta, Colombia. Remote Sens. Environ. 2008, 112, 2131-2144.

76. Petersson, H.; Holm, S.; Ståhl, G.; Alger, D.; Fridman, J.; Lehtonen, A.; Lundström, A.; Mäkipää, R. Individual tree biomass equations or biomass expansion factors for assessment of carbon stock changes in living biomass-A comparative study. For. Ecol. Manag. 2012, 270, 78-84.

77. Lehtonen, A.; Mäkipää, R.; Heikkinen, J.; Sievänen, R.; Liski, J. Biomass expansion factors (BEFs) for Scots pine, Norway spruce and birch according to stand age for boreal forests. For. Ecol. Manag. 2004, 188, 211-224.

78. Solberg, S.; Næsset, E.; Hanssen, K.H.; Christiansen, E. Mapping defoliation during a severe insect attack on Scots pine using airborne laser scanning. Remote Sens. Environ. 2006, 102, 364-376.

79. Sexton, J.O.; Bax, T.; Siqueira, P.; Swenson, J.J.; Hensley, S. A comparison of lidar, radar, and field measurements of canopy height in pine and hardwood forests of southeastern North America. For. Ecol. Manag. 2009, 257, 1136-1147.

80. Cartus, O.; Kellndorfer, J.; Rombach, M.; Walker, W. Mapping Canopy Height and Growing Stock Volume Using Airborne Lidar, ALOS PALSAR and Landsat ETM+. Remote Sens. 2012, 4, 3320-3345. 
81. Karjalainen, M.; Kankare, V.; Vastaranta, M.; Holopainen, M.; Hyyppä, J. Prediction of plot-level forest variables using TerraSAR-X stereo SAR data. Remote Sens. Environ. 2012, 117, 338-347.

82. Nagendra, H.; Lucas, R.; Honrado, J.P.; Jongman, R.H.G.; Tarantino, C.; Adamo, M.; Mairota, P. Remote sensing for conservation monitoring: Assessing protected areas, habitat extent, habitat condition, species diversity, and threats. Ecol. Indic. 2013, 33, 45-59.

83. Sun, G.; Ranson, K.; Kimes, D.; Blair, J.; Kovacs, K. Forest vertical structure from GLAS: An evaluation using LVIS and SRTM data. Remote Sens. Environ. 2008, 112, 107-117.

84. Treuhaft, R.N.; Chapman, B.D.; dos Santos, J.R.; Gonçalves, F.G.; Dutra, L.V.; Graça, P.M.L.A.; Drake, J.B. Vegetation profiles in tropical forests from multibaseline interferometric synthetic aperture radar, field, and lidar measurements. J. Geophys. Res. 2009, 114, doi:10.1029/2008 JD011674.

85. He, Q.-S.; Cao, C.-X.; Chen, E.-X.; Sun, G.-Q.; Ling, F.-L.; Pang, Y.; Zhang, H.; Ni, W.-J.; $\mathrm{Xu}$, M.; Li, Z.-Y.; Li, X.-W. Forest stand biomass estimation using ALOS PALSAR data based on LiDAR-derived prior knowledge in the Qilian Mountain, western China. Int. J. Remote Sens. 2012 , 33, 710-729.

86. Kantola, T.; Vastaranta, M.; Yu, X.; Lyytikainen-Saarenmaa, P.; Holopainen, M.; Talvitie, M.; Kaasalainen, S.; Solberg, S.; Hyyppa, J. Classification of Defoliated Trees Using Tree-Level Airborne Laser Scanning Data Combined with Aerial Images. Remote Sens. 2010, 2, 2665-2679.

87. Saatchi, S.S.; Harris, N.L.; Brown, S.; Lefsky, M.; Mitchard, E.T.A.; Salas, W.; Zutta, B.R.; Buermann, W.; Lewis, S.L.; Hagen, S.; et al. Benchmark map of forest carbon stocks in tropical regions across three continents. Proc. Natl. Acad. Sci. USA 2011, 108, 9899-9904.

88. Keightley, K.E.; Bawden, G.W. 3D volumetric modeling of grapevine biomass using Tripod LiDAR. Comput. Electron. Agric. 2010, 74, 305-312.

89. Raumonen, P.; Kaasalainen, M.; Åkerblom, M.; Kaasalainen, S.; Kaartinen, H.; Vastaranta, M.; Holopainen, M.; Disney, M.; Lewis, P. Fast Automatic Precision Tree Models from Terrestrial Laser Scanner Data. Remote Sens. 2013, 5, 491-520.

90. Calders, K.; Newnham, G.; Burt, A.; Murphy, S.; Raumonen, P.; Herold, M.; Culvenor, D.; Avitabile, V.; Disney, M.; Armston, J.; et al. Nondestructive estimates of above-ground biomass using terrestrial laser scanning. Methods Ecol. Evol. 2014, doi:10.1111/2041-210X.12301.

(C) 2015 by the authors; licensee MDPI, Basel, Switzerland. This article is an open access article distributed under the terms and conditions of the Creative Commons Attribution license (http://creativecommons.org/licenses/by/4.0/). 